Article

\title{
Do the Invasive Earthworms Amynthas agrestis (Oligochaeta: Megascolecidae) and Lumbricus rubellus (Oligochaeta: Lumbricidae) Stimulate Oxalate-Based Browser Defenses in Jack-in-the-Pulpit (Arisaema triphyllum) by Their Presence or Their Soil Biogeochemical Activity?
}

\author{
Ryan D. S. Melnichuk ${ }^{1}$, Hüseyin Barış Tecimen ${ }^{2}$ and Josef H. Görres ${ }^{3, * \mathbb{D}}$ \\ 1 Innotech Alberta, Edmonton, AB T6N 1E4, Canada; rdm7@ualberta.ca \\ 2 Soil Science and Ecology Department, Faculty of Forestry, Istanbul University-Cerrahpaşa, \\ 34473 Istanbul, Turkey; hbarist@gmail.com \\ 3 Department of Plant and Soil Science, University of Vermont, Burlington, VT 05405, USA \\ * Correspondence: jgorres@uvm.edu
}

check for updates

Citation: Melnichuk, R.D.S.; Tecimen, H.B.; Görres, J.H. Do the Invasive Earthworms Amynthas agrestis (Oligochaeta: Megascolecidae) and Lumbricus rubellus (Oligochaeta: Lumbricidae) Stimulate Oxalate-Based Browser Defenses in Jack-in-the-Pulpit (Arisaema triphyllum) by Their Presence or Their Soil Biogeochemical Activity? Soil Syst. 2022, 6, 11. https://doi.org/ 10.3390 /soilsystems6010011

Academic Editor: Klaus von Wilpert

Received: 29 November 2021

Accepted: 12 January 2022

Published: 18 January 2022

Publisher's Note: MDPI stays neutral with regard to jurisdictional claims in published maps and institutional affiliations.

Copyright: (c) 2022 by the authors. Licensee MDPI, Basel, Switzerland. This article is an open access article distributed under the terms and conditions of the Creative Commons Attribution (CC BY) license (https:// creativecommons.org/licenses/by/ $4.0 /)$.

\begin{abstract}
The introduction of invasive earthworms initiates physical and chemical alterations in previously earthworm-free forest soils, which triggers an ecological cascade. The most apparent step is the shift in the herbaceous plant community composition. However, some species, such as Arisaema triphyllum (jack-in-the-pulpit), persist where earthworms are present. It has been hypothesized that A. triphyllum produces insoluble oxalate, an herbivory deterrent, in the presence of earthworms. This study aimed to distinguish between the effects of earthworm-induced changes in soils and the physical presence of earthworms on oxalate production. As such, a two-way factorial greenhouse trial was conducted using uninvaded soils to test this hypothesis for two invasive earthworm species (Amynthas agrestis and Lumbricus rubellus). The sequential extraction of oxalates in A. triphyllum corms was performed with absolute ethanol, deionized water, acetic acid and $\mathrm{HCl}$, representing fractions of decreasing solubility. Earthworm presence increased water-soluble $(p=0.002)$ and total oxalate $(p=0.022)$ significantly, but only marginally significantly for HCl-soluble oxalate $(p=0.065)$. The corms of plants grown in soils previously exposed to the two species did not differ in oxalate production when earthworms were not present. However, the data suggest that earthworms affect corm oxalate concentrations and that the sequence of invasion matters for oxalate production by A. triphyllum.
\end{abstract}

Keywords: soil properties; forest soil modifications; oxalate; $A$. triphyllum; earthworm invasions; calcifery

\section{Introduction}

Earthworm invasions into previously uninvaded forests cause severe disturbances in forested ecosystems where the soils and plant community structure have developed in the absence of these invertebrates [1-4]. Specifically, the invasion of woodlands by earthworms results in the loss of organic soil horizons (through consumption of the $\mathrm{O}_{e}$ and $\mathrm{O}_{\mathrm{i}}$ layers) and a mixing of organic and mineral material [5], setting off an ecological cascade of effects that reach well beyond the forest soil and the immediately affected ecosystem [6]. With invasions now reaching into the ecosystems of the arctic circle [7,8], earthworms may affect the vast stocks of carbon stored in the taiga and tundra soils [9,10]. In the temperate regions of North America, the invasion is already well advanced and is affecting the plantsoil system [11-13], as well as whole ecosystems [1]. However, plant communities [14] are altered not only by the actions of earthworms but also by subsequent foraging by large ungulate browsers, such as white-tailed deer (Odocoileus virginianus) in North America [15]. Here, we examine a hypothesis that earthworms, or the changes they induce in the soils 
system, can result in the increased production of insoluble oxalates, an herbivory deterrent, in jack-in-the-pulpit (Arisaema triphyllum).

The vast majority of earthworms found in northeastern US forests are introduced species and have been recognized as such for some time [5,16-18]. Anthropogenic activities, such as horticulture, agriculture, non-commercial fishing, and recreation, have increased earthworm dispersal during the last century $[1,19,20]$. In contrast to agricultural lands, where they are regarded as positive indicators of soil quality (USDA-NRCS, 2001), earthworms have negative impacts on previously earthworm-free forest systems [14]. The mixing of organic and mineral soil by earthworms reduces the seedbank and germination function of the forest soil for many understory plants, often resulting in a decline in species richness and evenness [14,21-23], although abundance increases have also been observed, though often involving different species to the ones endemic to the region [21,24]. Additionally, the change in soil structure and the concomitant loss of the $\mathrm{O}_{\mathrm{i}}$ and $\mathrm{O}_{\mathrm{e}}$ horizons results in a flush of soluble nutrients early in the growing season, which may shift the phenology of the community to favor invasive plant species that may be able to utilize this unusually early abundance of an ordinarily limited resource [25]. Plants that remain are subject to greater browsing pressure from deer because of the lowered plant densities [22].

Some understory, "vermiphile" plants persist in the face of earthworm invasions $[14,22,26]$. Among plants that indicate the heavy infestation of forests by earthworms are Arisaema triphyllum, Allium tricoccum, Carex pensylvanica and saplings of Fraxinus species. Hypotheses regarding their resilience to earthworm invasions are several, but the one we investigated here relates to a potential chemical defense to browsing. Compounds likely to serve as a deterrent to browsers, such as oxalate, are often multifunctional, with additional roles in metabolism and structure [27]. An intermediate product of saccharide metabolism, compounds of oxalate can serve both as nutrient storage as well as an herbivory deterrent. For example, oxalate compounds with metal nutrients $(\mathrm{Ca}, \mathrm{Mg})$ to form sharp, insoluble raphides, intracellular needle-like crystals [28], that act as a sink for excess essential metals and represent a physical/chemical browser defense [27]. The oxalic acid exuded from root tips also immobilizes and prevents the uptake of toxic metals $(\mathrm{Al}, \mathrm{Hg}, \mathrm{Pb}, \mathrm{Cd})$ from soils or binds internally with those in plant tissues, making them metabolically inactive [29]. The focus of this study was to determine whether it is the mere presence of earthworms or the soil conditions caused by earthworm activity that affect plant oxalate production as well as the fractionation of oxalate compounds with different solubility.

The proposed mechanism of accelerated calcium oxalate $\left(\mathrm{CaC}_{2} \mathrm{O}_{4}\right)$ raphide formation is shown in Figure 1. It is based on the idea that earthworms accelerate the mineralization of Ca from organic matter by providing an additional mechanism of mineralization. However, many earthworms also have calciferous glands, which provide the calcium that neutralizes carbonic acid (a metabolic by-product) to form calcite $\left(\mathrm{Ca}\left(\mathrm{CO}_{3}\right)_{2}\right)$ in their gut [30]. This process, termed calcifery, results in the excretion of calcite granules by the earthworms. Calcite has low solubility, such that calcifery can sequester $\mathrm{C}$ and $\mathrm{Ca}$ into recalcitrant soil pools. However, the equilibrium chemistry of production and dissolution will elevate both labile and recalcitrant calcium carbonate pools in the soil, reaching a steady state after approximately 6 years [31]. In addition, calcifery requires that Ca is available, mineralized from organic matter, or released from the soil parent material.

Accelerated mineralization by earthworms promotes the availability of $\mathrm{Ca}$ and other base cations in soils. Some plants respond to greater Ca availability by storing it in compounds, such as Ca oxalate. We have observed that soils at earthworm-invaded sites had greater concentrations of available $\mathrm{Ca}$ (data not presented) which may trigger additional oxalate production in plants so that calcium in excess of cytosol requirement can be neutralized [32]. This adaptation allows these plants to tolerate the greater calcium concentrations that are purportedly associated with earthworms by storing it as calcium oxalate raphides. However, calcium relations in earthworms differ among species [33]. For example, Lumbricus rubellus is strongly calciferous, whereas Aporrectodea caliginosa is not. Calcium granule 
production for these two species is one to ten per day and one to ten per month, respectively $[33,34]$.

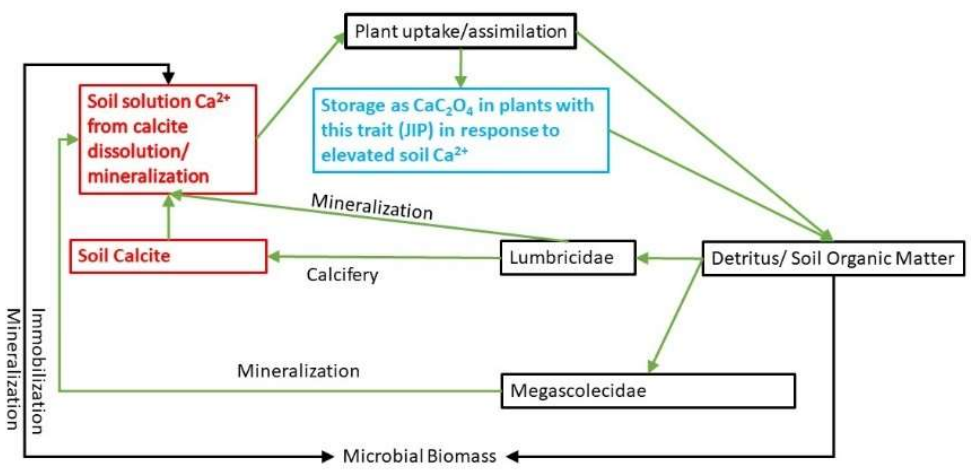

Figure 1. The role of earthworms in the formation of calcium oxalate $\left(\mathrm{CaC}_{2} \mathrm{O}_{4}\right)$ formation in vermiphile plants. Both Megascolecidae and Lumbricidae affect the soil solution $\mathrm{Ca}^{2+}$ through accelerated mineralization rates that are in addition to microbial mineralization. However, Lumbricidae also affects it through calcifery.

To test the hypotheses that earthworms promote insoluble oxalate production, jackin-the-pulpit (hereon in JIP, Arisaema triphyllum, Figure 2b), a known vermiphile plant species with established naturalized populations common in northern hardwood forest communities, was selected as the plant model [22]. Jack-in-the-pulpit is a calcium oxalateaccumulating plant native to the northeastern US that is anecdotally observed more often in the presence of earthworms. Calcium oxalate raphides in JIP are regarded as defenses against browsers, such as deer $[35,36]$.
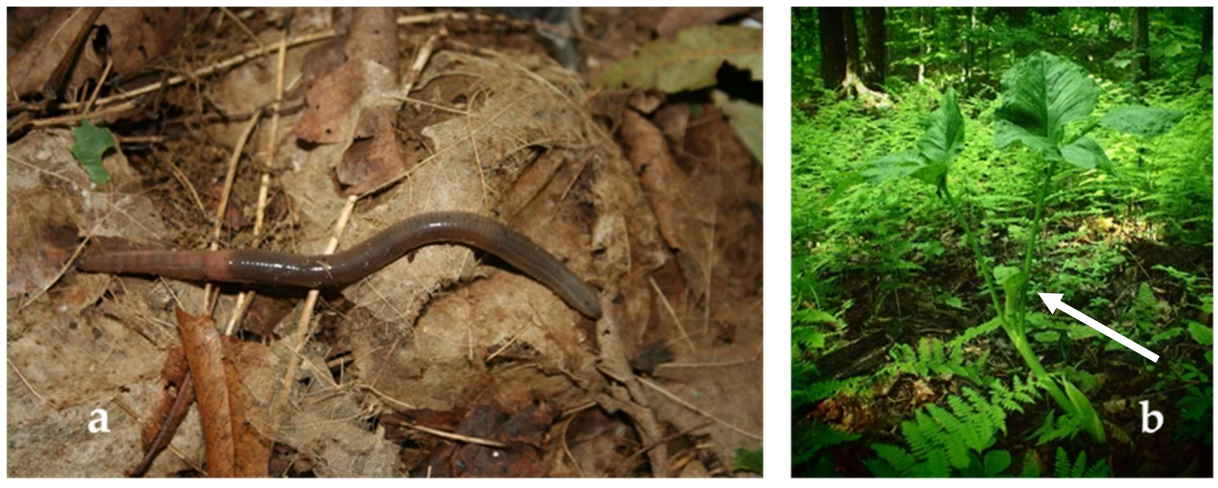

Figure 2. (a): Amynthas agrestis on the forest floor of a sugar maple stand at UVM's Horticultural Research Center in South Burlington, VT, and (b) jack-in-the-pulpit with large leaves in a sugar maple stand in the Champlain Valley, VT, USA. Arrow pointing at the inflorescence of the plant.

We selected Amynthas agrestis (Figure 2a) and L. rubellus as our model earthworms partly because they purportedly differ in soil calcium relations. They are both commonly observed, exotic, epi-endogenic earthworms found in the northeastern USA [17,37]. A. agrestis is of the family Megascolecidae and is one of three aggressive and rapidly dispersing earthworm species [20], with origins in far-eastern Asia. This species is part of a second wave of invaders which colonized northern North American soils already invaded by Lumbricidae [38], with potential further effects on soil-plant relations. Megascolecidae generally do not have calciferous glands [39], but it is possible that some species may have this adaptation. L. rubellus is of the family Lumbricidae, an almost ubiquitous, strongly calciferous earthworm with origins in Eurasia. Our objective was to separate as much as possible the influence of the edaphic conditions created previously by earthworms from the effect of their presence on plant concentrations of the oxalate compounds differing in solubility. We wanted to see (1) whether there was a difference in oxalate synthesis when calciferous 
or non-calciferous earthworms were present, (2) whether the effect of earthworms would last when they were removed and (3) whether the invasion sequence mattered, i.e., whether the second wave really does matter. To this end, we conducted an experiment in which the pre-incubation of soils with one or the other earthworm and without earthworms was one factor (SOIL), and the subsequent absence or presence of earthworms (WORM) was another factor (Figure 3A). The combination of pretreatment incubation in the absence of earthworms and the pots without earthworms serves as a control. Sequentially extracting oxalate along a solubility gradient may give insight into the effect of earthworms on oxalate storage as Ca oxalate, the form that deters browsers.
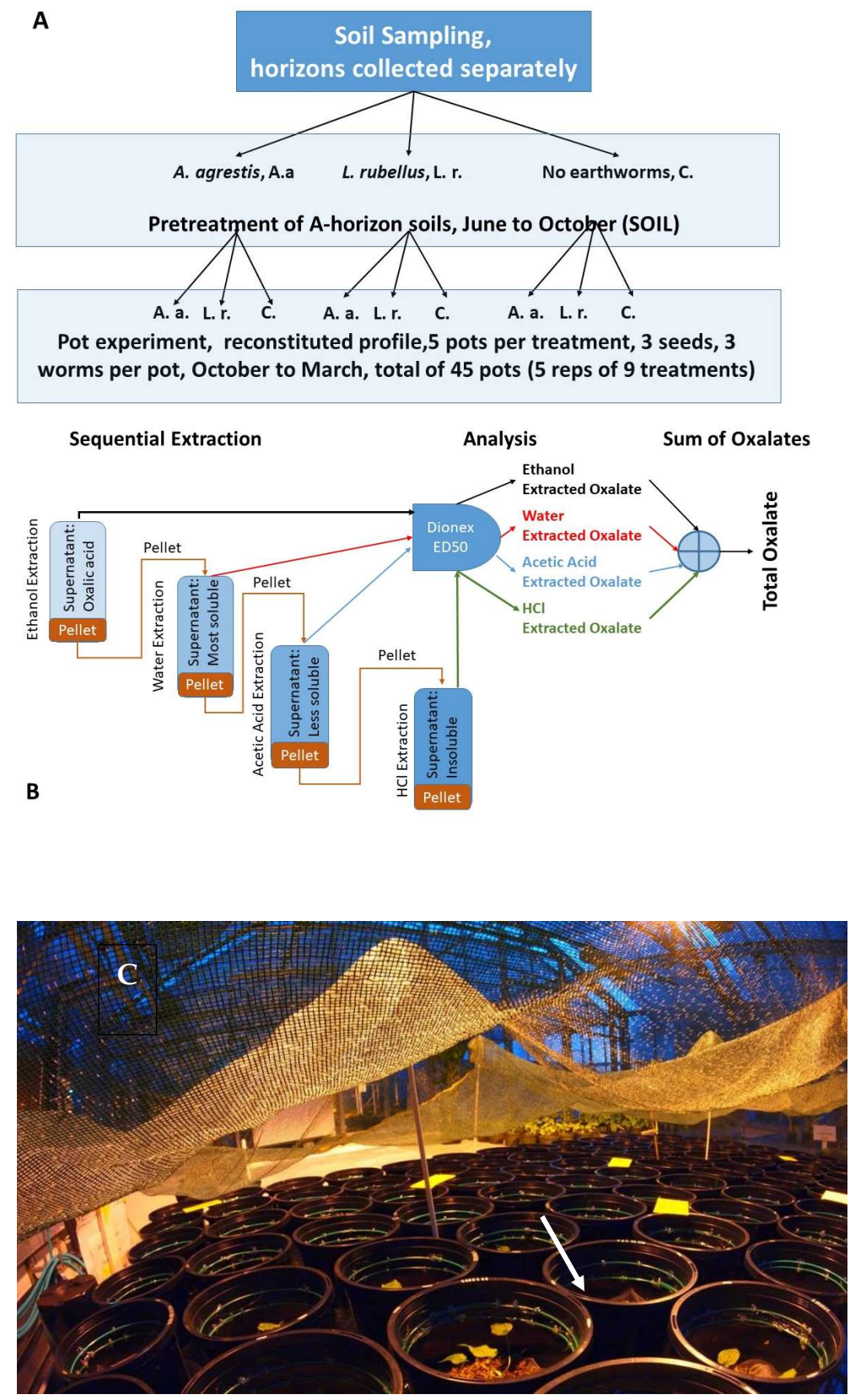

Figure 3. (A) Experimental design showing the relationship between soil pretreatments (SOIL) and pot treatments (WORM). A.a.-Amynthas agrestis, L.r.-Lumbricus rubellus, C.- - no earthworms added (control). (B) Sequential extraction of oxalate fractions, with solid fraction (pellet) from earlier extraction passed to next extraction. Total oxalates represents the sum of all solubility fractions. (C) Experimental setting in greenhouse showing shade cloth and pots with hook-up wire (arrow) a month after the initiation of the experiment. 


\section{Materials and Methods}

\subsection{Earthworm and Soil Collection}

Soil was collected from the University of Vermont Jericho Research Forest (latitude: $44^{\circ} 26^{\prime} 55^{\prime \prime} \mathrm{N}$, longitude: $72^{\circ} 59^{\prime} 48^{\prime \prime}$, elevation $230 \mathrm{~m}$ ) from an earthworm-free northern hardwood forest stand. The soil is mapped as Duane series, sandy-skeletal, mixed, frigid, ortstein Typic Haplorthods [40]. However, the observed profile better matches a Peru fine sandy loam (coarse-loamy, isotic, frigid Aquic Haplorthods) [40]. Each soil horizon (A, E, $\left.\mathrm{B}_{\mathrm{hs}}, \mathrm{B}\right)$ was collected from soil pits and stored separately until mesocosm construction. Mineral soil was sieved at $7.5 \mathrm{~mm}$ and the homogenized pass fraction was used in the experiment. Part of the A horizon was set aside to acclimate earthworms prior to the start of the experiment. The $\mathrm{O}_{\mathrm{a}}$ horizon, which was less than $2.5 \mathrm{~cm}$ thick in this soil series, was not collected. The leaf litter collected at the site was found to be predominantly sugar maple (Acer saccharum) and American beech (Fagus grandifolia). The leaf litter was manually shredded, and all materials were sieved at $7.5 \mathrm{~mm}$ and the pass fraction was used in the experiment.

A. agrestis (Figure 2a) were collected from naturalized populations at UVM's Horticulture Research Center (lat.: $44^{\circ} 25^{\prime} 52^{\prime \prime}$, long.: $73^{\circ} 11^{\prime} 57^{\prime \prime}$, elevation $112 \mathrm{~m}$ ) and L. rubellus from a field under a 7-year silage corn-alfalfa rotation at UVM's Miller Dairy Complex (lat.: $44^{\circ} 27^{\prime} 24^{\prime \prime}$, long.: $73^{\circ} 11^{\prime} 20^{\prime \prime}$, elevation $100 \mathrm{~m}$ ) both in South Burlington, VT. Earthworms were maintained in the aforementioned separate fraction of A horizon soil for 1 week to acclimate and ensure survival under experimental conditions.

In order to minimize variation amongst individuals, seeds of A.triphyllum, a dioecious perennial plant (Figure 2b), were purchased from a local sustainable wildflower horticulture center that collects and propagates native varieties (Vermont Wildflower Farm, Vergennes, VT, USA). Seeds were scarified and then stratified for 3 months prior to sowing into pots.

\subsection{Greenhouse Pot Trials}

The greenhouse trial was designed to examine the effect of soil modification by earthworms (SOIL), representing the "invasion history", and the effect of physical earthworm presence (WORM), representing new introductions, on JIP corm oxalate production. Thus, the experiment had three SOIL pretreatments in which earthworm-free soils were aged in the presence of L. rubellus or A. agrestis, or no earthworms at all (Figure 3A). Each of these pretreated soils was then subjected to three earthworm (WORM) treatments: No earthworms, A. agrestis or L. rubellus. In this way, we artificially created physical models of invasion sequences: invasions into soils not recently occupied by earthworms, $A$. agrestis following on from L. rubellus, and L. rubellus following A. agrestis.

To produce pretreated soils (SOIL), A horizon soil was divided into three shallow containers, each with a volume of $59 \mathrm{~L}$ ( $89 \mathrm{~cm}$ long, $42 \mathrm{~cm}$ wide, $16 \mathrm{~cm}$ deep). These containers were constructed to produce the three pre-experimental WORM treatments: (1) Control (no earthworms), (2) A. agrestis (140 $\mathrm{g}$ fresh biomass) and (3) L. rubellus (140 $\mathrm{g}$ fresh biomass). Pre-incubation started on 9 June 2012. The A horizon soil was incubated in the presence of the worms for 4.5 months on a $12 \mathrm{~h}$ day/night cycle at $15^{\circ} \mathrm{C}$. At the end of the preincubation period, earthworms were removed from the pretreated A horizon soil. Then, 45 experimental units were constructed in $4 \mathrm{~L}$, plastic horticultural pots by sequentially layering $B$, then $B_{h s}$, then $E$, then $A$ horizon, and lastly leaf litter into each vessel to simulate the soil profile as observed at the collection site. This was to create soil conditions similar to those found in field soil. Briefly, each pot contained $50 \mathrm{~g}$ of leaf litter, $800 \mathrm{~mL}$ A horizon, $30 \mathrm{~mL}$ E horizon, $400 \mathrm{~mL} \mathrm{~B}$ hs horizon and $2000 \mathrm{~mL}$ B horizon. Fifteen pots each received soils pretreated with A. agrestis, L. rubellus or neither earthworm. To five pots in each SOIL set, three $A$. agrestis, three L. rubellus or no earthworms were added on 29 October 2012. To prevent the escape of the earthworms, we modified the pots prior to reconstructing the soil profile. Two rings of single stranded insulated copper electrical wire (40 gage) were glued $1.5 \mathrm{~cm}$ apart to the inside of the pots $5 \mathrm{~cm}$ below the rim. As earthworms were moving over the two wires their adhesion to the pot walls were broken and they fell back 
onto the soil surface. In trials, this prevented $A$. agrestis from scaling the pot walls. A fine mesh was added to the bottom of the pots to prevents worms from escaping through the drainage holes.

All pots thus prepared were transferred to a greenhouse on 29 October 2012 and arranged in a complete randomized design under 12-h day/night cycle sodium supplemental lighting and 50\% shade cloth. Temperature was maintained between 15 and $21{ }^{\circ} \mathrm{C}$ and relative humidity varied at $50-100 \%$. Pots were misted equally with reverse osmosis water for the duration of the experiment at the replacement rate of the controls (WORM control on SOIL control). Each pot received 3 A. triphyllum seeds. Germination was high, with 2 or 3 seedlings emerging in each pot. Plants were continuously monitored until harvest, which was carried out one week after senescence when the corms from each treatment were collected on 13 March 2013.

Bulk samples of A horizon were collected from each pot and dried at $50{ }^{\circ} \mathrm{C}$. Standard $2 \mathrm{M} \mathrm{KCl}$ (mineral nitrogen) and $1 \mathrm{M} \mathrm{NH}_{4} \mathrm{Cl}$ (nutrients) extracts of 5:1 solvent to dry soil ratio were performed. Ammonium chloride extracts were analyzed using ICP-AES (Perkin-Elmer Corp., Norwalk, CT, USA). Mineral nitrogen was quantified colorimetrically on a BioTek 96well microtiter plate reader (BioTek, Winooski, VT, USA) using a miniaturized method [36]. In addition, relative dissolved organic matter content was analyzed for absorbance at 330 nm with a GENSYS10vis spectrophotometer (Thermo Scientific Spectronics, Rochester, NY, USA) [41].

Upon deconstruction of the soils, the contact between the A and B horizon was still distinct, but earthworm-related bioturbation and burrows were evident with the Bhs and some of the E horizons incorporated into the A and B horizons (Figure 4). The resulting contact between the A and the B horizon was wavy.

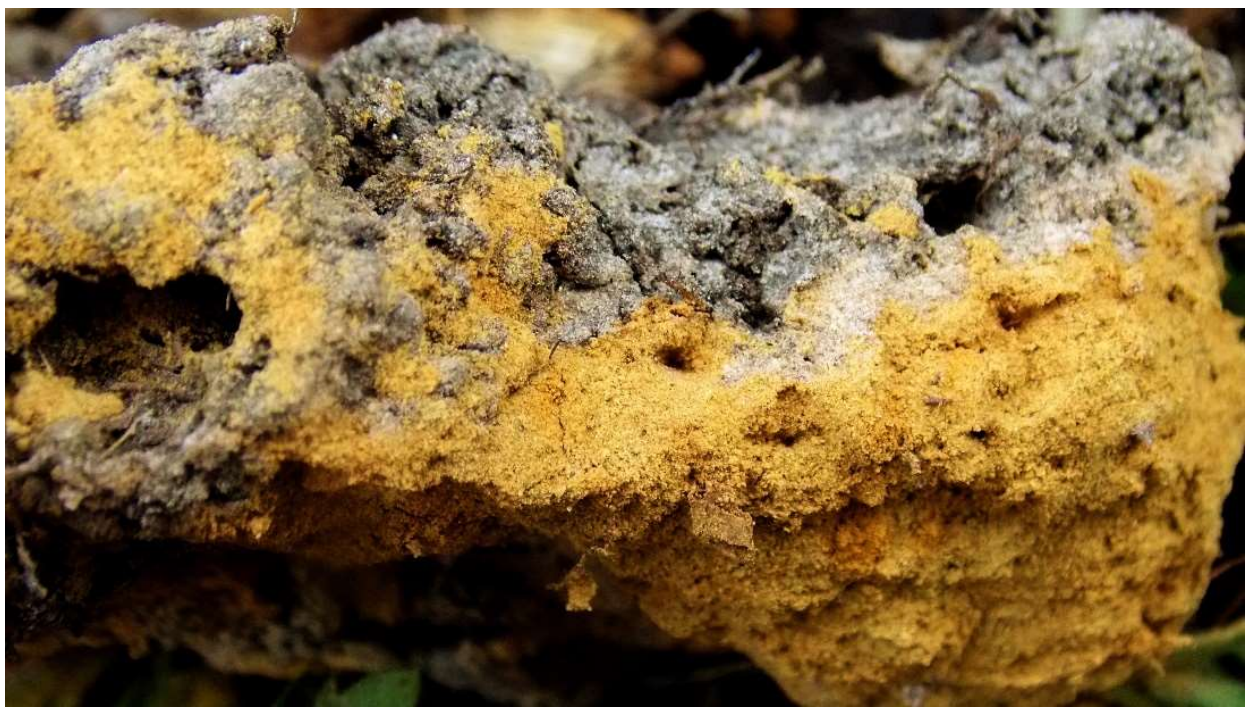

Figure 4. Soil after deconstruction of the pots. Dark soil at top is the A horizon, lighter patches below the A horizon are remnants of the E horizon, orange soil is the B horizon. Worm burrows are visible in both $\mathrm{A}$ and $\mathrm{B}$ horizons.

\subsection{Oxalate Quantification}

Several forms of variably soluble oxalate are present in plant tissues. We performed a sequential extraction with absolute ethanol, deionized water, 5\% acetic acid and $2 \mathrm{~N}$ $\mathrm{HCl}$, representing the oxalate fractions of decreasing solubility (Figure 3B). This method is operationally defined, but the ethanol fraction should contain only free oxalic acid, the water fraction should contain unbounded, polyhydrate and amorphous fractions of oxalate, the acetic acid fraction should contain the balance of non-crystalline forms of oxalate and the $\mathrm{HCl}$ fraction should contain the remaining forms (including Ca oxalate) of oxalate [42-45]. Because of the sequential extraction on the same sample, the total oxalate 
in a corm could be estimated as the sum of the extractions. Sequential solvent extraction was performed on fresh corms, which are tuber-like, below-ground storage organs, after surficial soil removal. Specifically, each corm was macerated, combined with $25 \mathrm{~mL}$ of ethanol and agitated with glass beads for $2 \mathrm{~h}$ at ambient conditions before centrifugation (TJ6 centrifuge; Beckman Coulter, Brea, CA, USA) and collection of supernatants. To pellet, $25 \mathrm{~mL}$ of water was added and the process was repeated. Acetic acid and $\mathrm{HCl}$ extraction were carried out in the same manner, with the exception that the $\mathrm{HCl}$ extract was agitated for $4 \mathrm{~h}$. The water content of the corms from each treatment were also analyzed, and no significant differences were observed. Extraction efficiency by mass was compared within treatments and found to not differ significantly.

Oxalate was quantified with a Dionex ED50 Electrochemical Detector (Sunnyvale, CA, USA) equipped with an AS50 Autosampler, an AS11 column and an AG11 guard column. A CSRS suppressor was included in the line to remove cations and contribution of gradient $\mathrm{NaOH}$ eluent (Dionex, Sunnyvale, CA, USA). A standard $20 \mathrm{mg} / \mathrm{L}$ oxalate solution was mixed at the beginning of the trial; aliquots were frozen and included as QCs in each run. Additionally, within each run, random samples were analyzed in duplicate to ensure replicable results.

\subsection{Aggregate-Scale Ca Concentrations}

To analyze whether the two earthworm species had different effects on soil microsite water-extractable Ca concentrations, we analyzed earthworm castings and compared them to aggregates formed in soils without earthworms. The experimental set up and analyses methods are given in Tecimen et al. [46]. In brief, aggregate samples were harvested from the following treatments described above: pretreatment control soil with no earthworms, L. rubellus or A. agrestis. The aggregates samples were extracted with deionized water and then immediately analyzed for Ca with an ion-specific microelectrode (Microelectrodes, Inc., Bedford, NH, USA).

\subsection{Statistics}

The mesocosm trial was a completely random, fully factorial design; the response variables (ethanol, water, acetic acid and $\mathrm{HCl}$ - extractable corm oxalates and total corm oxalates) were tested for homoscedasticity, independence and normality; if the data did not meet the assumptions, a transformation according to the natural log was performed. Subsequently, the data were examined by full two-way factorial ANOVA where the factors were SOIL (soil exposed to no earthworms, A. agrestis or L. rubellus) and WORM (no added earthworms, and A. agrestis or L. rubellus). In total, there were 9 treatments, which were replicated 5 times for 45 pots. All analyses were computed using JMP 11 (SAS Institute, Cary, NC, USA). The statistical model for the analysis of variance is given in Equation (1), where all factors are fixed effects:

$$
Y=\mu+\alpha_{i}+\beta_{j}+\alpha \beta_{i j}+\varepsilon_{i j k}
$$

where $\mu$ is the treatment mean, $\alpha$ is the SOIL treatment $(I=3), \beta$ is the WORM treatment $(j=3)$ and $\varepsilon$ is the error term $(k=5)$. Significant differences were evaluated post hoc with Tukey's HSD separately for each oxalate extraction. In addition, effect sizes were calculated as $\eta^{2}$ and partial $\eta^{2}$. These are expressions of the fraction of variance explained by each variable. In designs with more than one independent variable, partial $\eta^{2}$ calculates the effect of each variable with the variances of the other variables (and their interaction) removed from the total variance. It should be noted that the maximum value of $\eta^{2}$ and partial $\eta^{2}$ is less than 1 . For normally distributed variables, values vary between 0 and 0.64. Additionally, $\eta^{2}$ and partial $\eta^{2}$ values are classified into small $\left(0.0099<\eta^{2}<0.0588\right)$, medium $\left(>0.0588<\eta^{2}<0.1379\right)$ and large $\left(\eta^{2}>0.1379\right)$ effects [47].

For the comparison of Ca concentrations in aggregates, results were analyzed with a one-way ANOVA followed by Tukey's HSD test. 


\section{Results}

\subsection{Oxalate Fractions}

The water-extractable fraction was generally the largest fraction, followed by acetic acid fraction, then the $\mathrm{HCl}$-extractable fraction and finally the ethanol-extractable (free oxalic acid) fraction (Table 1). The ANOVA for ethanol-soluble and acetic acid-soluble oxalate did not detect any significant differences. However, for water-soluble and total oxalate, the ANOVA indicated significant differences ( $p=0.034$ and $p=0.042$, respectively). The effect tests showed that there was no significant difference in water-soluble oxalate among the SOIL treatments. Yet, for the WORM treatments, there was a difference in both water-soluble oxalate and total oxalates, with both earthworms having $27 \%$ greater watersoluble concentrations than the control. Total oxalate concentrations were $22.5 \%$ greater in the L. rubellus than the Control WORM treatments $(p=0.027)$. There were no significant differences between the L. rubellus and A. agrestis WORM treatments. The ANOVA showed marginally significant differences in $\mathrm{HCl}$-extractable oxalate among treatments $(p=0.065)$. Here, again, there was no significant differences among the SOIL treatments. However, in the WORM treatments, the $\mathrm{HCl}$ extractions were greater in the L. rubellus than the A. agrestis treatment. The exclusion of a statistical outlier increased the significance of the full ANOVA model and the WORM treatment $\mathrm{F}$ values $\left(\mathrm{F}_{8,44}=2.25, p=0.0465\right.$ and $\mathrm{F}_{2,35}=5.36, p=0.0093$ respectively). Statistical outliers are not necessarily biological outliers, so both values are included in the interest of transparency.

Table 1. Summary of full model and treatment effect statistical values for each extract fraction. The oxalate extracts vary left to right from low to high solubility. The mean and standard error of each treatment factor illustrate the effect where significantly different values are designated by different letters. The effect size $\left(\eta^{2}\right)$ and the partial effect size (partial $\eta^{2} \%$ ) are given as fractions of variance explained by soil, earthworm and their interaction. Effect size categories S (small), M (medium) and $\mathrm{L}$ (large) are also indicated for $\eta^{2}$.

\begin{tabular}{|c|c|c|c|c|c|c|}
\hline \multirow[b]{2}{*}{ Full Model } & & \multicolumn{5}{|c|}{ Oxalate Extract $(\mu g / g)$} \\
\hline & & Ethanol & Water & 5\% Acetic Acid & $2 \mathrm{~N} \mathrm{HCl}$ & Total \\
\hline & df & 8,44 & 8,44 & 8,44 & 8,44 & 8,44 \\
\hline & F-value & 1.113 & 3.954 & 0.322 & 2.073 & 3.150 \\
\hline & $p$-value & 0.378 & 0.002 & 0.952 & 0.065 & 0.011 \\
\hline \multicolumn{7}{|l|}{ Effect tests } \\
\hline \multirow[t]{5}{*}{ SOIL } & df & 2,36 & 2,36 & 2,36 & 2,36 & 2,36 \\
\hline & F-value & 0.549 & 1.391 & 0.349 & 0.169 & 0.935 \\
\hline & $p$-value & 0.582 & 0.262 & 0.708 & 0.845 & 0.402 \\
\hline & $\eta^{2 \%}$ & & $0.043(\mathrm{~S})$ & $0.015(\mathrm{~S})$ & $0.003(S)$ & $0.031(\mathrm{~S})$ \\
\hline & Partial $\eta^{2 \%}$ & & $0.074(\mathrm{M})$ & $0.016(\mathrm{~S})$ & $0.004(S)$ & $0.050(\mathrm{~S})$ \\
\hline \multirow[t]{5}{*}{ WORM } & $\mathrm{df}$ & 2,36 & 2,36 & 2,36 & 2,36 & 2,36 \\
\hline & F-value & 0.046 & 6.266 & 0.205 & 4.563 & 4.247 \\
\hline & $p$-value & 0.955 & 0.005 & 0.816 & 0.017 & 0.027 \\
\hline & $\eta^{2 \%}$ & & $0.189(\mathrm{~L})$ & $0.087(\mathrm{M})$ & $0.185(\mathrm{~L})$ & $0.137(\mathrm{M})$ \\
\hline & Partial $\eta^{2 \%}$ & & $0.255(\mathrm{~L})$ & $0.092(\mathrm{M})$ & $0.213(\mathrm{~L})$ & $0.187(\mathrm{~L})$ \\
\hline \multirow[t]{5}{*}{ SOIL*WORM } & df & 4,36 & 4,36 & 4,36 & 4,36 & 4,36 \\
\hline & F-value & 1.928 & 4.079 & 0.368 & 1.780 & 3.709 \\
\hline & $p$-value & 0.127 & 0.008 & 0.830 & 0.154 & 0.013 \\
\hline & $\eta^{2} \%$ & & $0.248(\mathrm{~L})$ & $0.041(S)$ & $0.129(\mathrm{M})$ & $0.245(\mathrm{~L})$ \\
\hline & Partial $\eta^{2 \%}$ & & $0.312(\mathrm{~L})$ & $0.042(\mathrm{~S})$ & $0.159(\mathrm{~L})$ & $0.292(\mathrm{~L})$ \\
\hline \multicolumn{7}{|c|}{ Treatment Mean (SE) } \\
\hline \multirow[t]{3}{*}{ SOIL } & Control & $35.6(4.7)$ & $585.2(41.8)$ & $300.7(40.1)$ & $171.6(21.0)$ & 1093.1(80.7) \\
\hline & A. agrestis & $29.6(3.1)$ & $513.6(39.4)$ & $264.8(22.7)$ & $187.9(25.1)$ & $995.9(59.6)$ \\
\hline & L. rubellus & $36.0(6.4)$ & $533.7(35.2)$ & $273.0(25.1)$ & $177.1(21.5)$ & 1019.7(39.7) \\
\hline \multirow[t]{3}{*}{ WORM } & Control & $33.0(5.3)$ & $453.7(39.8) \mathrm{a}$ & $269.3(24.5)$ & 161.2(24.6) ab & $917.2(52.3) \mathrm{a}$ \\
\hline & A. agrestis & $34.9(4.5)$ & $585.6(40.4) b$ & $296.0(40.1)$ & $147.1(14.0) \mathrm{a}$ & $1063.6(69.8) a b$ \\
\hline & L. rubellus & $33.3(5.0)$ & $593.1(25.5) b$ & 273.1(23.8) & $228.2(21.8) b$ & $1127.8(52.2) b$ \\
\hline
\end{tabular}

\subsection{Bulk Soil Chemistry}

Bulk soil analyses showed that available Fe was the only nutrient element with a significant difference among treatments (Table 2$)$ in the overall model $\left(\mathrm{F}_{8,44}=2.37, p=0.0367\right)$ 
with soil pretreatment contributing significantly to the variation $\left(\mathrm{F}_{2,36}=6.85, p=0.0030\right)$. The average $\mathrm{pH}$ of the soil was low at 3.91 [46]. Neither $\mathrm{NH}_{4} \mathrm{Cl}$-extractable Ca nor $\mathrm{NO}_{3}$ concentrations were significantly different among treatments. To meet parametric statistical requirements, absorbance at $330 \mathrm{~nm}$ was logarithmically transformed, resulting in significant difference in the overall model $\left(\mathrm{F}_{8,44}=5.04, p=0.003\right)$ and within SOIL treatments $\left(\mathrm{F}_{2,36}=18.8, p<0.0001\right)$ (Table 2$)$. In particular, the soils pretreated by A. agrestis had significantly greater dissolved organic matter content, estimated by absorbance, than the control $(p<0.0001)$ and L. rubellus-treated soils $(p=0.0356)$, regardless of the WORM treatment.

Table 2. Mean nutrient concentrations ( $\mathrm{mg} / \mathrm{kg}$ soil) of bulk soil after extraction with $\mathrm{NH}_{4} \mathrm{Cl}$. Standard errors $( \pm)$ are also given. Only Fe and $330 \mathrm{~nm}$ absorbance were significantly different among SOIL treatments.

\begin{tabular}{|c|c|c|c|c|c|c|c|c|c|c|c|c|c|}
\hline \multirow{3}{*}{$\begin{array}{l}\text { SOIL } \\
\text { Control }\end{array}$} & \multirow[b]{2}{*}{ WORM } & $\mathrm{Ca}$ & K & $\mathrm{Na}$ & $\mathrm{Al}$ & $\mathrm{Fe}$ & Mn & $\mathrm{Zn}$ & $\mathrm{Mg}$ & $\mathrm{NH}_{4}$ & $\mathrm{NO}_{3}$ & \multicolumn{2}{|c|}{$330 \mathrm{~nm}$} \\
\hline & & \multicolumn{10}{|c|}{ (mg/kg Soil) } & $\bar{x}$ & SE \\
\hline & Control & $939 \pm 202$ & $126 \pm 23.6$ & $46.3 \pm 8.2$ & $152 \pm 31.9$ & $36.3 \pm 5.3$ & $66.3 \pm 13.9$ & $7.08 \pm 0.39$ & $142 \pm 31.6$ & $33.1 \pm 9.3$ & $180 \pm 40.1$ & 0.267 & 0.049 \\
\hline & A. agrestis & $853 \pm 65$ & $129 \pm 12.6$ & $42.7 \pm 6.4$ & $164 \pm 15.1$ & $37.8 \pm 2.9$ & $68.3 \pm 9.2$ & $7.08 \pm 0.20$ & $142 \pm 7.8$ & $41.6 \pm 10.5$ & $230 \pm 60.6$ & 0.260 & 0.043 \\
\hline & L. rubellus & $1002 \pm 260$ & $177 \pm 38.1$ & $60.7 \pm 15.7$ & $170 \pm 8.2$ & $35.7 \pm 1.3$ & $72.0 \pm 17.1$ & $7.03 \pm 0.96$ & $178 \pm 41.7$ & $64.1 \pm 10.9$ & $370 \pm 111$ & 0.232 & 0.035 \\
\hline \multirow[t]{3}{*}{ A. agrestis } & Control & $1135 \pm 127$ & $189 \pm 25.8$ & $52.4 \pm 6.6$ & $116 \pm 20.4$ & $25.4 \pm 2.5$ & $96.9 \pm 13.5$ & $7.52 \pm 0.37$ & $204 \pm 18.4$ & $55.6 \pm 12.4$ & $301 \pm 80$ & 0.493 & 0.070 \\
\hline & A. agrestis & $1102 \pm 101$ & $197 \pm 31.6$ & $73.4 \pm 11.3$ & $124 \pm 15.6$ & $26.6 \pm 2.2$ & $89.5 \pm 11.7$ & $7.95 \pm 0.21$ & $200 \pm 19.5$ & $67.6 \pm 11.0$ & $345 \pm 61.3$ & 0.442 & 0.059 \\
\hline & L. rubellus & $1218 \pm 109$ & $189 \pm 22.2$ & $64.1 \pm 13.7$ & $119 \pm 16.1$ & $27.9 \pm 5.0$ & $102.0 \pm 6.6$ & $8.34 \pm 0.53$ & $219 \pm 26.0$ & $71.6 \pm 17.4$ & $366 \pm 94.8$ & 0.467 & 0.038 \\
\hline \multirow[t]{3}{*}{ L. rubellus } & Control & $959 \pm 148$ & $151 \pm 30.5$ & $41.1 \pm 9.8$ & $126 \pm 25.9$ & $29.7 \pm 3.9$ & $68.3 \pm 11.7$ & $7.06 \pm 0.77$ & $165 \pm 27.3$ & $39.0 \pm 13.2$ & $211 \pm 37.7$ & 0.339 & 0.036 \\
\hline & A. agrestis & $1146 \pm 121$ & $173 \pm 22.5$ & $55.8 \pm 6.8$ & $116 \pm 14.1$ & $30.7 \pm 1.8$ & $85.0 \pm 5.3$ & $7.46 \pm 0.35$ & $198 \pm 21.3$ & $54.5 \pm 10.9$ & $303 \pm 65.8$ & 0.395 & 0.051 \\
\hline & L. rubellus & $1125 \pm 141$ & $191 \pm 35.2$ & $84.2 \pm 14.0$ & $171 \pm 19.2$ & $39.1 \pm 2.9$ & $90.0 \pm 17.3$ & $8.76 \pm 0.66$ & $198 \pm 31.0$ & $77.8 \pm 13.5$ & $588 \pm 205$ & 0.303 & 0.019 \\
\hline
\end{tabular}

\subsection{Aggregate Scale Ca Concentrations}

The ANOVA revealed that water-extractable Ca concentrations were significantly different among aggregates formed by the earthworms and aggregates from the control $\left(\mathrm{F}_{2,117}=14.08, p<0.0001\right)$. The mean Ca concentrations (standard error) were 80.6 (2.63), 92.1 (2.28) and 110.9 (6.13) $\mathrm{mg} \mathrm{Ca} / \mathrm{kg}$ soil, for the control, A. agrestis and L. rubellus aggregates, respectively. Significant differences occurred between L. rubellus and A. agrestis $(p<0.0001)$ and L. rubellus and the control $(p<0.0042)$.

\section{Discussion}

\subsection{Oxalate Production by JIP}

\subsubsection{Effect of Earthworms (WORM)}

The results support the hypothesis that earthworms influence the oxalate production of JIP when earthworms were physically present (WORM) (Table 1). Only water- and $\mathrm{HCl}$-extractable oxalate fractions and total oxalates varied significantly between treatments. The $\mathrm{NH}_{4} \mathrm{Cl}$-extractable Ca concentrations in the bulk soils were not significantly different among treatments (Table 2), suggesting that there was no effect of soil Ca on oxalate production. However, when looking at water-extractable Ca concentrations in the aggregates, L. rubellus SOIL pretreatment had the largest Ca concentration, as one would expect for the calciferous earthworm. The magnitude of $\mathrm{HCl}$-extractable corm oxalate follows the same sequence as the aggregate scale, water-extractable Ca: it is greatest for L. rubellus SOIL, and lowest for the control SOIL treatment. The difference here may be both in the sample support (homogenized bulk soil versus frass aggregates) and the type of extraction, i.e., water versus $\mathrm{NH}_{4} \mathrm{Cl}$.

\subsubsection{Effect of the Soil Pretreatment (SOIL)}

The effect of pretreatment was not as clear cut as that of the WORM treatments because the full linear model showed no significant effect of SOIL, but a significant interaction between the two factors. To resolve the effect of SOIL, we analyzed it separately for the cases where no earthworms were added (WORM control) at the $p=0.10$ level. We found differences among SOIL treatments for the water-extractable and total oxalates (Figure 5A) with the three SOIL treatments explaining $36 \%$ of variation $\left(\eta^{2}=0.361\right)$ in the waterextractable oxalate and $44 \%$ in total oxalate variation $\left(\eta^{2}=0.441\right)$. Water-extractable oxalate concentrations in the corm grown in the L. rubellus-pretreated soil were greater than the concentrations in the corms of the A. agrestis pretreatment. Total oxalate concentrations 
in the corms grown in the calciferous L. rubellus soil were greater than in the A. agrestis pretreatment and Control pretreatment.
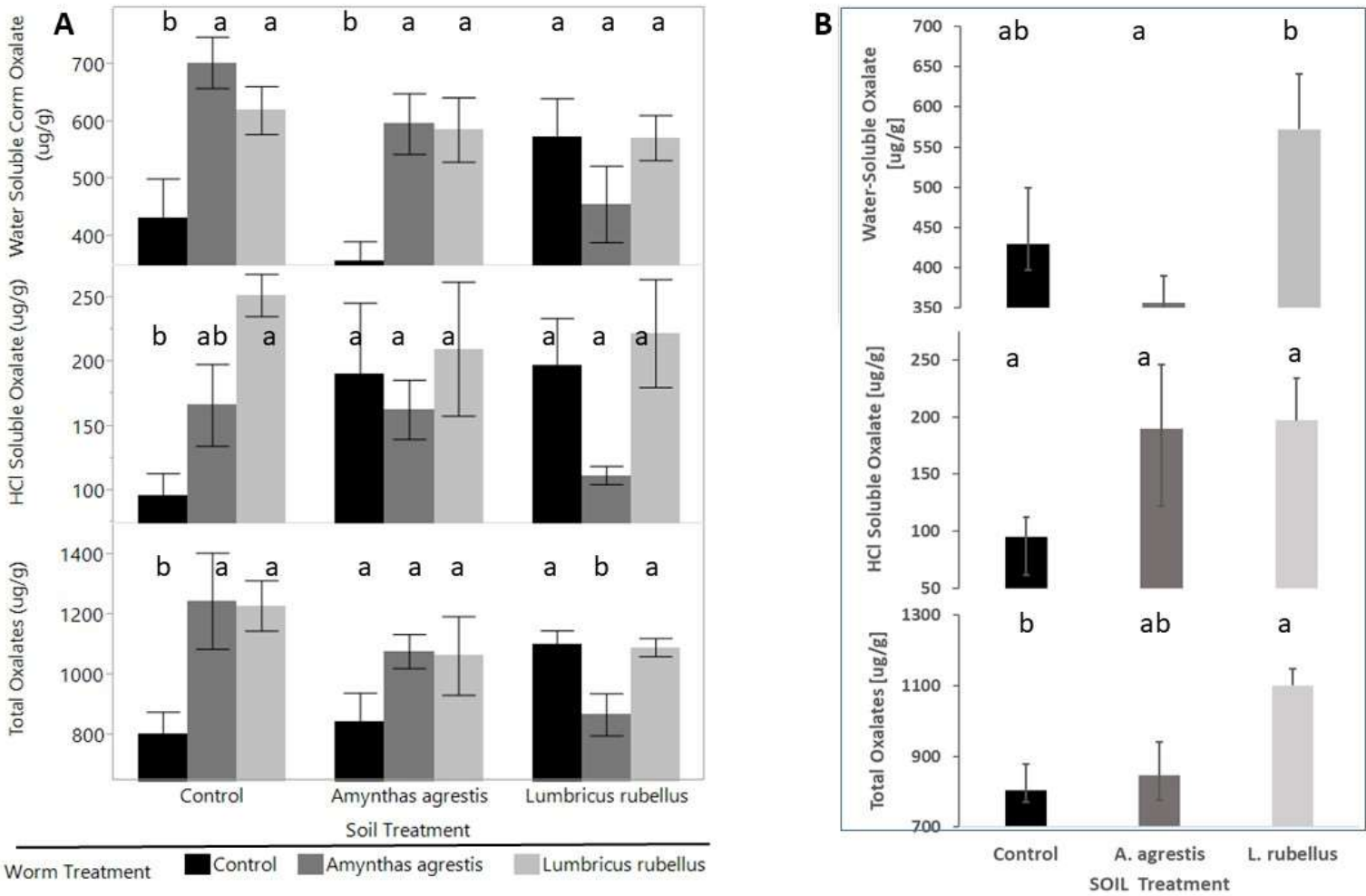

Figure 5. (A) Comparisons between SOIL treatment without any worms added, showing some effect of SOIL in the total and water-soluble oxalates. Different letters indicate significant differences at the $p=0.10$ level. (B) Water- and HCl-extractable oxalate and total oxalates as a function of earthworm and soil treatment. Error bars specify one standard error. Different letters indicate significant differences at the $p=0.05$ level for comparisons of WORM treatments within a SOIL pretreatment.

\subsubsection{Effect of Sequence of Earthworm Invasions}

In the current second wave of earthworm invasion [20] in the northeastern USA, Megascolecidae are replacing Lumbricidae. The concern is that the new invasion is further changing the ecosystems' response to earthworms. In this experiment, the sequence of invasions is modeled by adding earthworms to soils pretreated by earthworms. The invasion baseline would be the introduction of earthworms to soils previously unaltered by earthworms. In that case, the earthworm effects on water-soluble, $\mathrm{HCl}$-soluble and total oxalates were large and significant, regardless of which species was added (Figure 5B). The effect of earthworm invasions on soil chemistry is well known, although we were looking at the effect of earthworms on oxalates in plant tissue. Hale et al. [5] found large differences in field soil and leaf $\mathrm{N}$ concentrations across an invasion front of Lumbricidae in Minnesota. Price-Christenson et al. [48] showed similar effects for Amynthas agrestis and Amynthas tokioensis.

When examining the effect of earthworm addition to soils previously occupied by earthworms, three trends were interesting. First, when adding either A. agrestis or L. rubellus to $A$. agrestis SOIL treatment (Figure $5 \mathrm{~B}$ ), the addition of earthworms increased corm watersoluble oxalate concentrations significantly. Secondly, when introducing earthworms to L. rubellus-pretreated soils, L. rubellus did not affect any of the three oxalate fractions that showed any significance in the linear model: no difference was observed between no earthworm added and L. rubellus introductions. We expected that the combination of L. rubellus-pretreated soil and the presence of the calciferous L. rubellus would give a greater response. It is probable that the effect of an earthworm on JIP oxalate production is plastic, but bound by physiological constraints. Thirdly, water- and $\mathrm{HCl}$-extractable 
oxalate concentrations were lower when $A$. agrestis were introduced to the soil previously inhabited by L. rubellus, although the differences were not significant ( $p=0.32$ and $p=0.17$ for the water-soluble and $\mathrm{HCl}$-extractable oxalate, respectively). Yet, for total oxalate in the L. rubellus SOIL treatment, the addition of $A$. agrestis lowered the oxalate concentration significantly $(p=0.024)$. We did not design the experiment to understand the mechanisms of the plant response. However, the very different response when $A$. agrestis was added to L. terrestris soil may suggest that there are different mechanisms that drive oxalate production for the two worms.

It is not clear what the consequence of the reduction of oxalates in JIP would be in the field when $A$. agrestis displaces L. rubellus in the current "second wave" of earthworm invasion. Would the effect of oxalates as a grazing defense be lowered? It is important to note that we did not investigate the above-ground tissue, but a below-ground structure that is not accessible to grazers. While such a change could have an impact on forest plant communities, field research and further lab studies need to be conducted to ascertain such an effect.

\subsection{Effect of Soil Chemistry}

The conventionally held belief that plants can store excess $\mathrm{Ca}$, potentially mineralized from organic matter by earthworms, as Ca oxalate $[49,50]$ is difficult to invoke here because of the lack of significant differences in $\mathrm{NH}_{4} \mathrm{Cl}$-extracted $\mathrm{Ca}$ among soil pretreatments (Table 2). Lambkin et al. [31] estimated that for the soils they investigated, a steady state $\left(\mathrm{Ca}\left(\mathrm{CO}_{3}\right)_{2}\right)$ would only be reached after six years. Likely, the short period of time (4.5-8 months) that the soils were exposed to earthworms in this experiment would not have produced discernibly higher $\mathrm{Ca}$ accumulations. In addition, the low $\mathrm{pH}$ would also have promoted the dissolution of $\left(\mathrm{Ca}\left(\mathrm{CO}_{3}\right)_{2}\right)$.

The soil in the experiment had a very low $\mathrm{pH}$, which promotes high concentrations of aluminum and heavy metals. It has been observed that some plant species exude oxalate in response to aluminum and/or high heavy metal concentrations [50], which may have caused reduced concentrations of oxalate in the corms. We only considered oxalate concentrations at the end of the experimental period, but not the loss of oxalate from the corm in response to potential toxic metals that may be present in the soil at low $\mathrm{pH}$. The $\mathrm{pH}$ in the soils of this experiment was 3.91, lower than the $\mathrm{pKa}$ of aluminum. We also could not consider the redistribution of oxalate between the different solubility pools, which may also confound differences in oxalate activity among treatments. While high soil aluminum concentrations may have increased the exudation of oxalate, the high availability and uptake of $\mathrm{Ca}$ could have increased cytosolic oxalate production. Future studies are encouraged to disentangle what could possibly be opposing factors influencing plant oxalate concentrations, such as plant oxalate responses to soil $\mathrm{Al}$ and $\mathrm{Ca}$. If toxic metals result in the greater exudation of oxalate, then metal pollution could lower the resistance of $\mathrm{Ca}$ oxalate-accumulating plants to browsing and thus cause further reduction in understory biodiversity.

Downstream biotic influence could have driven the increased production of oxalate in the presence of earthworms. Pseudomonas oxalaticus and Actinomycetes both have the ability to decompose oxalate; this is relevant, as each have been found in the guts of earthworms [51]. Where earthworm geophagy takes place in the rhizosphere of the plants exuding oxalate, a decreased soil concentration of oxalate could trigger the plant to increase production. No direct detection of oxalate by plant roots has been reported; however, the indirect detection of shifts in soil $\mathrm{Al}$ and $\mathrm{Ca}$ concentration could increase the plant exudation of oxalate. Alternatively, experiments in which $\mathrm{Al}$, or other metals, and $\mathrm{Ca}$ are manipulated could improve our understanding of their effect on oxalate production.

Soil biochemical processes occur at microsites [52-55] which can be created by earthworms $[46,55]$. However, nutrient content is measured generally at much larger scales, thus averaging out any differences that may occur at microsites. While estimating nutrient availability at larger scales makes sense for nutrient management, it does not add to our 
understanding of the soil ecological processes that generally occur at the scale of the organisms involved. When we examined castings (aggregate-scale frass) there was indeed a difference in water-extractable soil Ca concentrations among the treatments. This form of Ca is immediately available to plants, and thus might be more important for signaling to the plant to produce more oxalate. In addition, corms and roots may be intersecting microsites associated with aggregates where chemical stimuli may be concentrated.

We were particularly surprised that there were so few differences in soil nutrient concentrations among treatments, even when comparing soils with earthworms to earthwormfree controls. Others have shown that nitrification is promoted by earthworms [56-58], especially in the drilosphere [56]. Nitrate concentrations in our mesocosms were high compared to other investigators, though our trial was comparatively twice as lengthy [59]. Nitrate concentrations reported by Burtelow et al. [57] were similar to our soils, although they observed differences between earthworm and earthworm-free soils. It is possible that any differences between treatments were masked by the scale of our measurement, which would have averaged out the effect of the drilosphere. Alternatively, the longer experimental period compared to others may have resulted in a depletion of available nitrogen, as no fertilizer was added to the microcosms. Moreover, soil nitrogen may have been immobilized by the plants and soil fauna prior to soil sampling. To note, differences in nitrate concentrations may have not been observed because of our method of analysis; the microplate method employed is best for screening, and so a comparatively low precision may have introduced more error than other methods.

Finally, when comparing the SOIL treatments, A. agrestis had greater dissolved organic carbon (measured as light absorbance at $330 \mathrm{~nm}$ ) than the control or L. rubellus-pretreated soils. This either suggests that $A$. agrestis is mobilizing organic carbon for microbial use more so than $L$. rubellus or that the microbiome associated with its castings is not processing it.

\subsection{Biological Significance of Results}

Statistical and biological significance may not be same in regards to plant oxalate concentration and fitness. Trials on nutrition and herbivory deterrent effectiveness in Medicago truncata have demonstrated that oxalate decreases herbivory and nutrition in rats and chewing insects, though these model plants were knock-out genotypes (with no oxalate production) [60,61]. The effects of slight changes in concentration, as seen here, may be more difficult to determine over short experimental durations. A possible future study on the interaction of a castrating pathogen, Uromyces atriphyllia, and the reproductive success of JIP in the presence and absence of earthworms would be a natural progression from what has been examined here. In addition, an experiment that examines the natural range of oxalate production in JIP, as well as under various nutrient regimes, would be advised.

The observed effects of earthworms on oxalate concentrations in JIP corms suggest that there might be an effect of previous earthworm occupancy at the time of invasion. When $A$. agrestis invades a soil with $L$. rubellus, the production of oxalate in the plant corm is suppressed. Could this have any effect on the palatability of the plant? The literature suggests that $\mathrm{Ca}$ oxalate raphides, needle-like structures, are one defense against herbivores [60,62]. However, a synergistic effect occurs when other defensive factors are present, such as other needle-like structures, such as silica raphides, or chemical defenses, such as cysteine protease [63]. Synergism could amplify the effect of smaller amounts of $\mathrm{HCl}$-extractable oxalate, which is presumably associated with Ca oxalate crystals. When L. rubellus invades an A. agrestis patch, there may not be an effect on oxalate concentrations. When either worm invades earthworm-free soil, plant oxalate concentrations increase. In our greenhouse experiment, the differences developed quickly over a six-month period.

\section{Conclusions}

Earthworms increase some oxalate fractions in the corms of JIP, even when the soils had been occupied by earthworms up to the beginning of the assay. In this study the hypothesis that increased concentrations of oxalate in plant tissue were mediated by $\mathrm{Ca}$ 
in the bulk soil was not confirmed. However, focusing on microsites, here represented by earthworm casts, did show greater water-extractable Ca concentrations for L. rubellus than for the other treatments.

In this experiment, introducing A. agrestis to soils previously inhabited by L. rubellus reduced corm oxalate accumulation. In the other two soils (control and habitation by A. agrestis), corm accumulations of oxalate were the same for both earthworms at the time scale examined. This might mean that the introduction of A. agrestis to soils previously inhabited by L. rubellus may affect the plant community by reducing the synthesis of the oxalate compounds potentially involved in deterring herbivores.

Author Contributions: Conceptualization, R.D.S.M. and J.H.G.; methodology, R.D.S.M., H.B.T. and J.H.G.; formal analysis, R.D.S.M. and J.H.G.; investigation, R.D.S.M. and H.B.T.; writing-original draft preparation, R.D.S.M. and J.H.G.; writing-review and editing, H.B.T., R.D.S.M. and J.H.G.; visualization, R.D.S.M.; supervision, J.H.G., project administration, J.H.G.; funding acquisition, J.H.G. All authors have read and agreed to the published version of the manuscript.

Funding: This research was funded by the College of Agriculture and Life Science at the University of Vermont, the Scientific Research Projects Coordination Unit of Istanbul University under grant number 18262.

Conflicts of Interest: The authors declare no conflict of interest.

\section{References}

1. Bohlen, P.J.; Scheu, S.; Hale, C.M.; McLean, M.A.; Migge, S.; Groffman, P.M.; Parkinson, D. Non-native invasive earthworms as agents of change in northern temperate forests. Front. Ecol. Environ. 2004, 2, 427-435. [CrossRef]

2. Hendrix, P.F.; Baker, G.; Callaham, M.A.; Damoff, G.; Fragoso, C.; Gonzalez, G.; James, S.; Lachnicht, S.L.; Winsome, T.; Zou, X. Invasion of exotic earthworms into ecosystems inhabited by native earthworms. In Biological Invasions Belowground: Earthworms as Invasive Species; Springer: Dordrecht, The Netherlands, 2006; pp. 87-100.

3. Frelich, L.E.; Hale, C.M.; Reich, P.B.; Holdsworth, A.R.; Scheu, S.; Heneghan, L.; Bohlen, P.J. Earthworm invasion into previously earthworm-free temperate and boreal forests. In Biological Invasions Belowground: Earthworms as Invasive Species; Springer: Dordrecht, The Netherlands, 2006; pp. 35-45.

4. Tiunov, A.V.; Hale, C.M.; Holdsworth, A.R.; Vsevolodova-Perel, T.S. Invasion patterns of Lumbricidae into the previously earthworm-free areas of northeastern Europe and the western Great Lakes region of North America. In Biological Invasions Belowground: Earthworms as Invasive Species; Springer: Dordrecht, The Netherlands, 2006; pp. 23-34.

5. Hale, C.M.; Frelich, L.E.; Reich, P.B.; Pastor, J. Effects of European earthworm invasion on soil characteristics in northern hardwood forests of Minnesota, USA. Ecosystems 2005, 8, 911-927. [CrossRef]

6. Frelich, L.E.; Blossey, B.; Cameron, E.K.; Dávalos, A.; Eisenhauer, N.; Fahey, T.; Ferlian, O.; Groffman, P.M.; Larson, E.; Loss, S.R.; et al. Side-swiped: Ecological cascades emanating from earthworm invasions. Front. Ecol. Environ. 2019, 17, 502-510. [CrossRef]

7. Wackett, A.A.; Yoo, K.; Cameron, E.K.; Olid, C.; Klaminder, J. Global Wo'rming and Darwin Revisited: Quantifying Soil Mixing Rates by Non-native Earthworms in Fennoscandian Boreal and Arctic Ecosystems. In Proceedings of the AGU Fall Meeting Abstracts, New Orleans, LA, USA, 11-15 December 2017; p. B21F-2002.

8. Makarova, O.; Kolesnikova, A. Earthworms (Oligochaeta, Lumbricidae) in the tundra of Eastern Europe. Biol. Bull. 2019, 46, 438-449. [CrossRef]

9. Arvidsson, E. Invasive Earthworms and Their Effect on Soil Organic Matter: Impact on Soil Carbon 'Quality'in Fennoscandian Tundra. 2021. Available online: https://www.diva-portal.org/smash/get/diva2:1565059/FULLTEXT01.pdf (accessed on 20 October 2021).

10. Lejoly, J.; Quideau, S.; Laganière, J. Invasive earthworms affect soil morphological features and carbon stocks in boreal forests. Geoderma 2021, 404, 115262. [CrossRef]

11. Lawrence, B.; Fisk, M.C.; Fahey, T.J.; Suarez, E.R. Influence of nonnative earthworms on mycorrhizal colonization of sugar maple (Acer saccharum). New Phytol. 2003, 157, 145-153. [CrossRef] [PubMed]

12. Paudel, S.; Longcore, T.; MacDonald, B.; McCormick, M.K.; Szlavecz, K.; Wilson, G.W.; Loss, S.R. Belowground interactions with aboveground consequences: Invasive earthworms and arbuscular mycorrhizal fungi. Ecology 2016, 97, 605-614. [CrossRef]

13. Blume-Werry, G.; Krab, E.J.; Olofsson, J.; Sundqvist, M.K.; Väisänen, M.; Klaminder, J. Invasive earthworms unlock arctic plant nitrogen limitation. Nat. Commun. 2020, 11, 1-10. [CrossRef]

14. Hale, C.M.; Frelich, L.E.; Reich, P.B. Changes in hardwood forest understory plant communities in response to European earthworm invasions. Ecology 2006, 87, 1637-1649. [CrossRef]

15. Fisichelli, N.; Eisenhauer, N.; Frelich, L.; Reich, P. Deer and Earthworms Modify Forest Responses to Climate Change; NPS Climate Change Response Program: Washington, DC, USA, 2013. 
16. Reynolds, J.W. The earthworms of Tennessee (Oligochaeta). IV. Megascolecidae, with notes on distribution, biology and a key to the species in the state. Megadrilogica 1978, 3, 117-129.

17. Reynolds, J.W.; Görres, J.H.; Knowles, M.E. A checklist by counties of earthworms (Oligochaeta: Acanthodrilidae, Lumbricidae and Megascolecidae) in the states of Maine, New Hampshire and Vermont, USA. Megadrilogica 2015, 17, 125-140.

18. Alban, D.H.; Berry, E.C. Effects of earthworm invasion on morphology, carbon, and nitrogen of a forest soil. Appl. Soil Ecol. 1994, 1, 243-249. [CrossRef]

19. Cameron, E.K.; Bayne, E.M.; Clapperton, M.J. Human-facilitated invasion of exotic earthworms into northern boreal forests. Ecoscience 2007, 14, 482-490. [CrossRef]

20. Chang, C.-H.; Johnston, M.R.; Görres, J.H.; Dávalos, A.; McHugh, D.; Szlavecz, K. Co-invasion of three Asian earthworms, Metaphire hilgendorfi, Amynthas agrestis and Amynthas tokioensis in the USA. Biol. Invasions 2018, 20, 843-848. [CrossRef]

21. Addison, J. Distribution and impacts of invasive earthworms in Canadian forest ecosystems. Biol. Invasions 2009, 11, 59-79. [CrossRef]

22. Holdsworth, A.R.; Frelich, L.E.; Reich, P.B. Effects of earthworm invasion on plant species richness in northern hardwood forests. Conserv. Biol. 2007, 21, 997-1008. [CrossRef]

23. Drouin, M.; Bradley, R.; Lapointe, L.; Whalen, J. Non-native anecic earthworms (Lumbricus terrestris L.) reduce seed germination and seedling survival of temperate and boreal trees species. Appl. Soil Ecol. 2014, 75, 145-149. [CrossRef]

24. Nuzzo, V.; Dávalos, A.; Blossey, B. Invasive earthworms shape forest seed bank composition. Divers. Distrib. 2015, 21, 560-570. [CrossRef]

25. Blouin, M.; Hodson, M.E.; Delgado, E.A.; Baker, G.; Brussaard, L.; Butt, K.R.; Dai, J.; Dendooven, L.; Pérès, G.; Tondoh, J. A review of earthworm impact on soil function and ecosystem services. Eur. J. Soil Sci. 2013, 64, 161-182. [CrossRef]

26. Corio, K.; Wolf, A.; Draney, M.; Fewless, G. Exotic earthworms of great lakes forests: A search for indicator plant species in maple forests. For. Ecol. Manag. 2009, 258, 1059-1066. [CrossRef]

27. Franceschi, V.R.; Nakata, P.A. Calcium oxalate in plants: Formation and function. Annu. Rev. Plant Biol. 2005, 56, 41-71. [CrossRef]

28. Black, O. Calcium oxalate in the Dasheen. Am. J. Bot. 1918, 5, 447-451. [CrossRef]

29. Mazen, A.; El Maghraby, O. Accumulation of cadmium, lead and strontium, and a role of calcium oxalate in water hyacinth tolerance. Biol. Plant. 1997, 40, 411-417. [CrossRef]

30. Briones, M.; López, E.; Méndez, J.; Rodríguez, J.; Gago-Duport, L. Biological control over the formation and storage of amorphous calcium carbonate by earthworms. Mineral. Mag. 2008, 72, 227-231. [CrossRef]

31. Lambkin, D.C.; Gwilliam, K.H.; Layton, C.; Canti, M.G.; Piearce, T.G.; Hodson, M.E. Production and dissolution rates of earthworm-secreted calcium carbonate. Pedobiologia 2011, 54, S119-S129. [CrossRef]

32. Webb, M.A. Cell-mediated crystallization of calcium oxalate in plants. Plant Cell 1999, 11, 751-761. [CrossRef] [PubMed]

33. Piearce, T. The calcium relations of selected Lumbricidae. J. Anim. Ecol. 1972, 41, 167-188. [CrossRef]

34. Canti, M.G.; Piearce, T.G. Morphology and dynamics of calcium carbonate granules produced by different earthworm species: The 7th International Symposium on Earthworm Ecology·Cardiff.Wales·2002. Pedobiologia 2003, 47, 511-521.

35. Bierzychudek, P. The demography of jack-in-the-pulpit, a forest perennial that changes sex. Ecol. Monogr. 1982, 52, 335-351. [CrossRef]

36. Sims, G.; Ellsworth, T.; Mulvaney, R. Microscale determination of inorganic nitrogen in water and soil extracts. Commun. Soil Sci. Plant Anal. 1995, 26, 303-316. [CrossRef]

37. Bellitürk, K.; Görres, J.H.; Kunkle, J.; Melnichuk, R.D.S. Can commercial mulches be reservoirs of invasive earthworms? Promotion of ligninolytic enzyme activity and survival of Amynthas agrestis (Goto and Hatai, 1899). Appl. Soil Ecol. 2015, 87, 27-31. [CrossRef]

38. Chang, C.; Szlavecz, K.; Bernard, M.; Pitz, S. The second wave of earthworm invasion: Soil organic matter dynamics from the stable isotope perspective. In Proceedings of the 2013 AGU Fall Meeting, San Francisco, CA, USA, 9-13 December 2013. Abstracts B31C-0423.

39. Plisko, J.D.; Nxele, T.C. An annotated key separating foreign earthworm species from the indigenous South African taxa (Oligochaeta: Acanthodrilidae, Eudrilidae, Glossoscolecidae, Lumbricidae, Megascolecidae, Microchaetidae, Ocnerodrilidae and Tritogeniidae). Afr. Invertebr. 2015, 56, 663-708. [CrossRef]

40. Soil Survey Staff, Natural Resources Conservation Service, United States Department of Agriculture. Web Soil Survey. Available online: http:/ / websoilsurvey.sc.egov.usda.gov / (accessed on 10 October 2021).

41. Moore, T. Patterns of dissolved organic matter in subarctic peatlands. Earth Surf. Processes Landf. 1987, 12, 387-397. [CrossRef]

42. Ferguson, I.B.; Turner, N.A.; Bollard, E.G. Problems in fractionating calcium in plant tissue. J. Sci. Food Agric. 1980, 31, 7-14. [CrossRef]

43. Libert, B.; Franceschi, V.R. Oxalate in crop plants. J. Agric. Food Chem. 1987, 35, 926-938. [CrossRef]

44. Zindler-Frank, E.; Hönow, R.; Hesse, A. Calcium and oxalate content of the leaves of Phaseolus vulgaris at different calcium supply in relation to calcium oxalate crystal formation. J. Plant Physiol. 2001, 158, 139-144. [CrossRef]

45. Hönow, R.; Hesse, A. Comparison of extraction methods for the determination of soluble and total oxalate in foods by HPLCenzyme-reactor. Food Chem. 2002, 78, 511-521. [CrossRef]

46. Tecimen, H.B.; Gorres, J.H.; Melnichuk, R.D. Effect of Lumbricus rubellus and Amynthas agrestis earthworms on soil biogeochemistry at the aggregate scale in northern hardwood forests. J. Sustain. For. 2020, 40, 1-16. [CrossRef] 
47. Richardson, J.T. Eta squared and partial eta squared as measures of effect size in educational research. Educ. Res. Rev. 2011, 6, 135-147. [CrossRef]

48. Price-Christenson, G.J.; Johnston, M.R.; Herrick, B.M.; Yannarell, A.C. Influence of invasive earthworms (Amynthas spp.) on Wisconsin forest soil microbial communities and soil chemistry. Soil Biol. Biochem. 2020, 149, 107955. [CrossRef]

49. White, P.J.; Broadley, M.R. Calcium in plants. Ann. Bot. 2003, 92, 487-511. [CrossRef]

50. Poschenrieder, C.; Gunsé, B.; Corrales, I.; Barceló, J. A glance into aluminum toxicity and resistance in plants. Sci. Total Environ. 2008, 400, 356-368. [CrossRef]

51. Cromack, K., Jr.; Sollins, P.; Todd, R.; Fogel, R.; Todd, A.; Fender, W.; Crossley, M.; Crossley, D., Jr. The role of oxalic acid and bicarbonate in calcium cycling by fungi and bacteria: Some possible implications for soil animals. Ecol. Bull. 1977, $25,246-252$.

52. Parkin, T.B. Soil microsites as a source of denitrification variability. Soil Sci. Soc. Am. J. 1987, 51, 1194-1199. [CrossRef]

53. Sexstone, A.J.; Revsbech, N.P.; Parkin, T.B.; Tiedje, J.M. Direct measurement of oxygen profiles and denitrification rates in soil aggregates. Soil Sci. Soc. Am. J. 1985, 49, 645-651. [CrossRef]

54. Görres, J.H.; Savin, M.C.; Neher, D.A.; Weicht, T.R.; Amador, J.A. Grazing in a porous environment: 1 . The effect of soil pore structure on C and N mineralization. Plant Soil 1999, 212, 75-83.

55. Görres, J.H.; Savin, M.C.; Amador, J.A. Soil micropore structure and carbon mineralization in burrows and casts of an anecic earthworm (Lumbricus terrestris). Soil Biol. Biochem. 2001, 33, 1881-1887. [CrossRef]

56. Amador, J.A.; Görres, J.H.; Savin, M.C. Carbon and Nitrogen Dynamics in (L.) Burrow Soil. Soil Sci. Soc. Am. J. 2003, 67, 1755-1762. [CrossRef]

57. Burtelow, A.E.; Bohlen, P.J.; Groffman, P.M. Influence of exotic earthworm invasion on soil organic matter, microbial biomass and denitrification potential in forest soils of the northeastern United States. Appl. Soil Ecol. 1998, 9, 197-202. [CrossRef]

58. Parkin, T.B.; Berry, E.C. Microbial nitrogen transformations in earthworm burrows. Soil Biol. Biochem. 1999, 31, $1765-1771$. [CrossRef]

59. Amador, J.A.; Potts, D.A.; Savin, M.C.; Tomlinson, P.; Görres, J.H.; Nicosia, E.L. Mesocosm-scale evaluation of faunal and microbial communities of aerated and unaerated leachfield soil. J. Environ. Qual. 2006, 35, 1160-1169. [CrossRef]

60. Li, X.; Yang, J.; Morris, J.; Hester, A.; Nakata, P.A.; Hirschi, K.D. Genetically modified Medicago truncatula lacking calcium oxalate has increased calcium bioavailability and partially rescues vitamin D receptor knockout mice phenotypes. J. Bioequiv. Bioavailab. 2013, 5, 47-52. [CrossRef]

61. Korth, K.L.; Doege, S.J.; Park, S.-H.; Goggin, F.L.; Wang, Q.; Gomez, S.K.; Liu, G.; Jia, L.; Nakata, P.A. Medicago truncatula mutants demonstrate the role of plant calcium oxalate crystals as an effective defense against chewing insects. Plant Physiol. 2006, 141, 188-195. [CrossRef] [PubMed]

62. Ward, D.; Spiegel, M.; Saltz, D. Gazelle herbivory and interpopulation differences in calcium oxalate content of leaves of a desert lily. J. Chem. Ecol. 1997, 23, 333-346. [CrossRef]

63. Konno, K.; Inoue, T.A.; Nakamura, M. Synergistic defensive function of raphides and protease through the needle effect. PLoS ONE 2014, 9, e91341. [CrossRef] 